\title{
Introduction: Beyond the Silk Roads
}

'Our country is at the heart of Asia', Zia, an Afghan trader in his midfifties who works in St Petersburg's Apraksin Dvor market, remarked to me in December 2015. 'Yet if the heart has all the qualities that allow the entire body to function, so too is the heart - as pressure increases and the veins block - the place where if one thing goes wrong the entire body fails.' Along with a further 100,000 Afghans living across the Russian Federation, and thousands in Ukraine, Belarus and the Central Asian states, Zia makes a living selling goods imported from China to Russian buyers. Such goods are mostly sold on a wholesale basis in large markets often identified by scholars and policymakers as being the sites of the post-Soviet world's 'informal economy'. It is impossible to calculate with any degree of accuracy the monetary size of this type of activity, not least because many of the goods in which traders such as Zia deal are imported to the Russian Federation without the completion of formal customs procedures. But the size of the markets in which these traders work, alongside the vibrant nature of the commercial cities in China in which they purchase commodities, indicates a sizeable contribution to postSoviet economies.

This book is a study of the connective networks and supporting corridors that bind together different parts of Eurasia. In the last five years, China's Belt and Road Initiative has brought Eurasian connectivity to the heart of global discussions about development and geopolitics. ${ }^{1}$ The vantage point that Beyond the Silk Roads takes on regional connectivity, however, is not that of China's policymakers, but of traders from Afghanistan, one of the world's most turbulent countries. I conducted fieldwork with traders in Afghanistan but also in the vibrant commercial

${ }^{1}$ The Belt and Road Initiative is China's infrastructural development strategy that was announced in 2013 and seeks to promote global and regional connectivity by way of the development of Central Asian land routes and Indo-Pacific sea routes. See: Clarke 2017, Fallon 2015, Ferdinand 2016, Gladney 1994, Ploberger 2017, Rolland 2017a, Winter 2019. 
nodes in which traders from the country operate, spending time with them in their shops in Kabul, offices in China's 'international trade city' of Yiwu, as well as in wholesale markets in Jeddah, Istanbul, Odessa, London and St Petersburg. The book identifies and focuses on two transregional 'corridors of connectivity' along which the traders operate: one connecting China and the post-Soviet world, and the other that involves Central Asian traders linking China to West Asia. Its chief concern is with the ability of traders active across these human-commercial corridors to navigate between fraught geopolitical worlds. By documenting this critical dimension of their everyday lives, and its effects on their identities, Beyond the Silk Roads seeks to illuminate aspects of Asian connectivity that are not fully accounted for in an expanding and increasingly sophisticated body of literature on inter-Asian dynamics that treats regions as 'fluid and interconnected', rather than 'fixed and self-contained' and explores the relevance of notions of 'the Silk Road' and 'the Eurasian arena' to understanding this. ${ }^{2}$ Describing and analysing the experiences of mobile traders, the networks they form and the multiple inter-Asian commercial nodes in which they operate, the book illuminates the relevance, resilience and ongoing vitality of their commercial activities, histories, communities and geographies.

From the US New Silk Roads strategy, launched by Hillary Clinton in Chennai in July 2011, to the Chinese Belt and Road Initiative, announced by President Xi Jinping in 2013, forms of 'regional connectivity' driven by state policy have come to be regarded as key to the future of unstable states in Central Asia such as Afghanistan and to global economic growth more generally. The trope of the Silk Road has also grown in stature in scholarship on Asia. The concept has increasingly come to be used as a window for understanding global history at its most expansive scale. ${ }^{3}$ It has also been deployed to reveal the state of geopolitical dynamics and tensions in Asia and Europe today. ${ }^{4}$ The focus on such megaprojects of trade and infrastructure is understandable. Yet the emphasis given to 'state-driven, state-centric and state-controlled' visions of regional connectivity has had a silencing effect on the ongoing significance of the lived forms of Eurasian connections that are the central focus of this study. ${ }^{5} \mathrm{At}$ the same time, the scholarly fixation with 'the local' and 'the global' has resulted in comparatively little attention being paid to the types of sustained transregional connections forged by men such as Zia.

\footnotetext{
${ }^{2}$ Huat et al. 2019: 40. $\quad{ }^{3}$ Frankopan 2015. $\quad{ }^{4}$ Frankopan 2018.

5 Van Schendel 2020: 39.
} 


\section{From a Central Asian Oasis City to the Black Sea: Beginnings}

My interest in inter-Asian trading networks dates to my first visit to Pakistan in 1995. In 1995-1996, I spent a year teaching English at a small school in Chitral - a mountainous and relatively remote district of northern Pakistan that shares a border with Afghanistan and in parts lies only miles from the post-Soviet state of Tajikistan. In Chitral, the lively and diverse commercial roles played by Afghans in villages and small towns was a striking feature of daily life. Chitral Town, the district's administrative headquarters, was home to tens of thousands of Afghans, many from the country's northern provinces of Panjshir and Badakhshan. These Afghans sold all manner of goods in the bazaar, ranging from the type of waistcoats worn by Afghan mujahidin fighters to handicrafts chiselled out of Lapis Lazuli that were popular among the Western tourists who visited Chitral during the summer months. There were also shops in the bazaar that functioned largely as money exchange and transfer agents. The Afghans living in remoter villages also travelled far and wide, and often across the border between Afghanistan and Pakistan, to purchase livestock that they then slaughtered and sold in Chitral. ${ }^{6}$

The following year, I returned to Pakistan, spending six weeks in Chitral but also making a trip along the Karakoram Highway in order to visit the city of Kashgar in China's Xinjiang autonomous region. Today, little remains of the architecture of this historic oasis city other than a street preserved for the mostly Han Chinese tourists who continue to visit it. In 1996, however, Kashgar's old city remained largely intact; groups of elderly Uyghurs sat around in the town's central mosque square and in the teahouses (chaykhana) dotting its street discussing the day's events. Another equally memorable aspect of my brief time in the city was staying at the Chini Bagh Hotel, a ramshackle establishment housed in the buildings of the nineteenth-century British consulate that had a pleasant garden to while away the hot summer nights. Aside from a handful of other tourists and backpackers, many of the other guests in the hotel were traders from Pakistan visiting Kashgar to procure small commodities, especially batteries and jewellery. At the time, China had recently embarked on the policy of 'opening up', though it did not go on to join the World Trade Organization until 2001. Most traders from Pakistan visited north-western China in specially organised groups doing so facilitated their securing visas and the relevant documents they required in order to trade. Most of the traders with whom I spoke in the

\footnotetext{
${ }^{6}$ For a detailed discussion, see Chapter 6 in Marsden and Hopkins (2012).
} 
smattering of Pashtu I had learned in Chitral identified themselves as being ethnolinguistic Pashtuns from eastern Afghanistan, though they had travelled to China using Pakistani passports. Indeed, many were the descendants of families that had moved to Pakistan from Afghanistan in the 1960 s, a decade or so before the country's invasion by the Soviet Union. The traders appeared to pass their days well in Kashgar. At the time, the city was predominantly Muslim. As a result, traders from Pakistan and Afghanistan faced few if any of the issues procuring suitable halal food that they would in later years as they moved their commercial operations to the country's eastern seaboard.

My encounters with these transborder Pashtun itinerant merchants came back to me vividly in June 2012 during a visit to Ukraine's Black Sea port of Odessa. I had travelled to Odessa after hearing about a lively community of Afghans living there from Afghan friends and anthropologist colleagues who had conducted research in the city. ${ }^{7} \mathrm{~A}$ healthy proportion of the 4,000 Afghans who lived in Odessa had been educated in Ukraine during the Soviet period. At that time, the Soviet Union played an active role in the politics and economy of Afghanistan. During the time that I spent in Odessa in 2012, one of the most informative and open of the many Afghans I met was Gulzad, a man in his late forties who hailed from Afghanistan's eastern city of Jalalabad. Gulzad took me to Odessa's beach most evenings during my three-week stay in Odessa. We chatted about our experiences while playing volleyball in the warm waters of the Black Sea. In the evenings, my new friend invited me to take tea in an Afghan-style guest room he had built in the house he owned in the city's outskirts, showing me the chillies and okra that his wife grew in the garden with seeds brought from eastern Afghanistan. During the day, I would visit the shop he ran from a container in Odessa's renowned Sidmoi or 'Seventh-Kilometre' Market - a sprawling market in which migrants and immigrants purvey imported goods from inside row upon row of containers. Gulzad's friends regularly told me how generous he was, but one also shared with me a word of warning, 'make sure you don't compete too hard when we play volley ball in the sea because if you cross him you will be in difficulties'.

Like me, Gulzad - along with one of his friends who also lived in Odessa in 2012 - had spent much time living in Chitral during the 1990s. Back then, the two friends sold Chinese batteries and Indian-made bangles to local Chitrali villagers. They also worked with traders in the district who oversaw a healthy business in the procurement and sale of scrap plastic items such as sandals. Gulzad reminisced about how Chitral's cool nights

${ }^{7}$ Skvirskaja 2012. 
had offered a welcome respite from the suffocating hear of Peshawar, the capital of what was then referred to as Pakistan's North West Frontier Province until being officially designated as Khyber Pakhtunkhwa in 2010. In addition to having spent time in Chitral, Gulzad had in those years also travelled regularly to Kashgar - we speculated that we had been in the city at around the same time. Far from being a simple purveyor in small commodities like the traders with whom I had interacted in the Chini Bagh Hotel, Gulzad had engaged in more complex operations and transactions during his visits to China in the mid-1990s. One activity he told me about was his role as a financier for Arabs who contracted Pakistanis to travel to the Xinjiang region and capture birds of prey for export to Pakistan and from there on to the Gulf states. A difficulty faced by the Pakistani hawk hunters was the payment of labour costs to the Chinese locals who worked for them. At the time, the Chinese authorities strictly enforced legislation relating to currency conversion and the bringing of cash in and out of China. Gulzad visited China on officially sponsored trade visits that facilitated the export of goods to Pakistan through officially sanctioned barter schemes. As a result, he was able to pay the salaries and living costs of the Chinese labourers who worked for the Pakistani hawk hunters by providing them with Indian-made bangles, which they could then go on to sell in Xinjiang's markets. Gulzad made a profit from such activities by selling Chinese goods on his return to Pakistan.

In the years to come, such skills would come to shape Gulzad's development as a trader. From his involvement in the transborder trade between Pakistan and China, Gulzad went on to establish a trading office in the mid-2000s in the Chinese city of Yiwu - a global hub for the purchase of 'small commodities' located in the wealthy eastern province of Zhejiang and about which we will learn a great deal later in this book. He eventually moved to Ukraine and established himself in the wholesale of commodities imported from China. Gulzad wore his trans-Eurasian background as a mark of distinction: he told me that he had made his first visit to Ukraine by land by way of China, Kazakhstan and Russia and without carrying a single identification document.

As I studied different aspects of the social dynamics of Pakistan and Afghanistan and the interactions between these societies and the wider world through migration, I began to recognise the significant role the traders I had come to know played in connecting regions of Asia rarely thought about in relation to one another. Relatively few discussions of the importance of such traders, their routes and the networks to which they belonged existed in the literature on contemporary forms of inter-Asian commerce. Those studies that did address such communities tended to 
view them through the lens of 'migration' or 'refugee studies', focusing upon the social and political barriers to everyday life, citizenship and integration within the societies in which they had settled. Other studies focused narrowly on the way in which trade was a livelihood strategy in times of political and economic upheaval. And within this literature there was also the tendency to focus on the experiences of racially distinct communities - Africans in China, for instance. The fortunes and experiences of mobile people from adjacent regions within Eurasia was less regularly the focus of sustained attention and analysis. I also found little substantial recognition of the lives of men and women who had adapted to life in the countries in which they had settled and - mostly through a combination of commerce and marriage into local communities - had subsequently earned positions of status and respect.

As my research progressed, international projects such as the 'New Silk Road' and the 'Belt and Road Initiative' grew increasingly powerful and important. More and more focus turned to the effect of new infrastructures on Asia's geopolitics. As a result, the forms of trade that had animated commerce, exchange and mobility in the region for decades before the design of geopolitical and infrastructural megaprojects in regional and international capitals were further marginalised from discussions about the nature and benefits of regional connectivity. Indeed, existing forms of trade were increasingly regarded as the archaic hangover of a time gone by, or as constituting the 'survival strategy' of destitute and marginal refugee and migrant communities in the context of war, social breakdown and the dissolution of older political structures, especially those of the Soviet Union.

Having seen people I had known in Chitral in the mid-1990s transform into actors such as the eminently transnational Gulzad in Odessa in the second decade of the twenty-first century, it was clear to me that existing understandings represented just one aspect of a much more layered history. In order to understand the multiple influences that Afghans brought to their trading activities across Eurasia, I spent the next eight years visiting the commercial centres that traders told me were significant to their work. ${ }^{8}$ These ranged from the modern cosmopolitan trading city of Yiwu in China to the historic ports of Istanbul and Jeddah in West Asia; they also incorporated many smaller cities and towns in between. During these visits, I met and spoke to hundreds of traders. Some - like Gulzad - were people I had come to know, which allowed me to follow them to different places as and when they moved. Others were introduced ( $m a^{\prime}$ arefi) to me - often using telephones or social

\footnotetext{
${ }^{8}$ For the precise dates and location of the fieldwork, see 'Note on Fieldwork'.
} 
media - by my established contacts: on hearing that I would be visiting a location in which they had friends, associates and business partners, they would give me the contact details of people I should speak to on my arrival. I learned in meetings with such traders how individuals built on their cumulative experience of inter-Asian trade and deployed this knowledge in the different settings across which they worked.

As we shall see later, historians have emphasised the ways in which Eurasian commercial communities have acted in culturally flexible ways while at the same time building durable networks and identities. ${ }^{9}$ A combination of both sets of skills played a critical role in the ability of networks to trade, both over long distances and over extended periods of time. In his study of Armenian trading networks centred on the city of New Julfa in Iran, Sebouh David Aslanian suggests that Armenian traders in the early modern period are helpfully thought of as 'transimperial cosmopolitans' as a result of their ability to straddle linguistic, political and religious boundaries. ${ }^{10}$ In similar terms, Gagan Sood, in his study of Eurasian trading networks in the early modern period, demonstrates that traders from a wide variety of religious and cultural backgrounds communicated with one another through their use of a shared Persian vernacular, itself heavily inflected with standard idioms and key phrases. ${ }^{11}$

As I spent more and more time with Afghan merchants in Eurasian contexts, I came to see how modern institutions, most especially those associated with the nation state, have irrevocably changed the worlds explored by historians. Such transformations are evident in the material presented in this book, most especially in terms of traders' fraught relationships with the citizenship regimes of the countries across which they move. In some contexts, the traders appeal for formal citizenship - or at least the forms of protection and security it is regarded as conferring on individuals and their families - on the basis of marriage, the relationships they build with local officials and displays of loyalty to the nation states they inhabit. In other settings in which they are unable to secure legal access to citizenship, traders seek to build relationships with governments elsewhere that do grant citizenship, often in a manner that reflects the traders' understanding of complex geopolitical dynamics. They may also seek a degree of security by emphasising their cultural and historic connections to a particular society - what anthropologists often refer to as 'flexible' or 'cultural' citizenship - even if doing so cannot fully address the precarious legal uncertainties that animate many aspects of their daily

\footnotetext{
${ }^{9}$ For a pioneering attempt to explain the forms of cultural brokerage practised by 'trade diasporas', see Curtin, 1984 and see also Baghdiantz-McCabe, Harlaftis and Pepelasis Minoglou 2005.

${ }^{10}$ Aslanian 2014: 66. ${ }^{11}$ Sood 2016: 130-33.
} 
lives. ${ }^{12}$ This strategy is, for example, particularly evident in the case of traders of Turkic ethnolinguistic groups that are currently based in Turkey - we will meet these traders in Chapter 3.

Yet against the backdrop of such transformations, parallels between earlier and contemporary trading structures, identities and modes of mobile life are also visible. Traders thrive in the intermediate zones between competing geopolitical projects. They are able to make and handle competing loyalties to political entities and projects. And, for the traders, cultural and linguistic versatility is widely regarded as a necessary quality for life in the connected contexts of Eurasia. Given that they enact such modes of being in a wider context intersected by multiple geopolitical projects, the designation of actors such as Gulzad as contemporary 'transimperial cosmopolitans' assumes an even more direct relevance.

\section{Beyond the Silk Roads}

This book brings attention and definition to the alternative geographies authored by traders such as Gulzad and the communities and the histories of connectivity with which they are entangled; it does so in two major ways.

First, Beyond the Silk Roads aims to analyse the role played by 'informal traders' in connecting China to multiple Asian settings. In order to do so, it focuses not on the traders' economic practices but on the types of networks and communities important to the traders, as well as the routes along which goods, people and ideas travel. ${ }^{13}$ It does so against the backdrop of the broader geopolitical contexts in which the traders act, and asks how these contexts inform and are informed by the traders' personal and collective identities and strategies. In particular, the book builds on but also seeks to extend scholarship that distinguishes between forms of economic globalisation forged from 'the bottom-up' and those orchestrated 'top-down' by nation states and international organisations. ${ }^{14}$ International boundary crossing mobility is a central aspect of the traders' livelihoods. As a result, the traders upon whom the book focuses are routinely exposed to and sensitive of geopolitical shifts. I emphasise how in order to participate in commercial forms of connective activity, merchants must learn to navigate multiple projects of 'geopolitical engineering' and the forms of political and

12 Ong 1999.

${ }^{13}$ On the economic aspects of the traders' activities and relationships, see Chapter 1 of Marsden 2016. An extensive body of literature within the field of 'economic anthropology' explores the business models of Eurasia's informal traders. For an overview, see Fehlings and Karrar 2020.

${ }^{14}$ Mathews, Lins Ribeiro and Alba 2012. 
cultural 'divergence' these inevitably spawn. ${ }^{15}$ The traders, I argue, are adept at contending with such tensions through the conduct of informal or everyday diplomacy. They also build institutions that are the product of, and able to withstand, shifts in geopolitical configurations through time. ${ }^{16}$ In the course of such activities, the traders forge transnational routes and nodes of circulation that channel significant flows of people, resources and ideas. The routes and nodes authored by the traders are of interest to state actors who react to them in a range of ways, including attempting to regulate them, capitalising directly from them or using them as channels to extend the influence and reach of the states they serve across national boundaries.

In this sense, the book develops an anthropological approach to the study of geopolitics as lived. The approach I develop departs from the conventional tendency to assume that the sphere of geopolitics is the preserve of state actors alone and inherently external to society, impinging upon everyday life but not being shaped by it. The traders on whom the book focuses do not merely carry out the same role as state actors, diplomats and strategists in the commercial rather than political sphere or in an informal rather than formal idiom. Nor is it the relative paucity of the resources available to traders as compared with those available to states that distinguishes the role they play in geopolitical processes. The anthropological approach to 'lived geopolitics' that I advance in the book, rather, resists locating groups such as the traders explored in the following pages as being either 'above' or 'below' the state. It focuses, instead, on recognising that the context in which they act is located in the interstices between geopolitical projects, including those across time (as in the case of the shift in forms of Eurasian connectivity promoted by the USSR to those developed by China) and space (between Russian and Turkish conceptions of Eurasian connectivity, for instance). It is unhelpful to think of mobile Afghan traders, I suggest, in terms of their being either opposed to state boundaries and geopolitical projects or simply derivative of them. The traders are themselves authors of geographical routes, connections and imaginations - this distinguishes them from business communities originating in nation states that are playing a major role in promoting projects of Eurasian connectivity. Unlike political projects such as ISIS that directly challenge the international order, however, the transregional routes and geographical imaginations the traders author are imbricated and layered in a complex and inherently

15 Van Schendel 2020: 39.

${ }^{16}$ The term 'informal diplomacy' is increasingly used by scholars across a range of disciplines to analyse the 'intermediation between states through the interaction of non-state actors'. See Yolaçan 2019: 37. 
contingent way with 'official' geopolitics; an analysis of their activities thus requires a consideration of specific spatial and temporal contexts.

Second, Beyond the Silk Roads is also about the lives and experiences of the individuals involved in this type of trade and mobility: tens of thousands of traders from countries including Afghanistan, Syria, Yemen, Tajikistan and Uzbekistan travel frequently between their home countries, as well as the third settings in which they live, to China in order to procure goods for export. Settled communities of traders, moneychangers and export agents from these countries and many others besides live in China's commercial cities, as well as in vibrant and interconnected trading nodes across Eurasia. Decades before the launch of the Belt and Road Initiative, these communities and networks were playing a pivotal role in the movement of Chinese commodities across Eurasia. Today, they are also increasingly active in the import of critical products - agricultural and natural resources in particular - to China.

This book takes as its point of empirical departure the role played in Eurasian connectivity by traders from or connected to Afghanistan. The story it tells, however, is much broader than one connected to any single group, community or nation state. This is something revealed in the diversity of actors from Afghanistan involved in the forging of such connections.

Zia's remarks about his country acting as Asia's throbbing heart demonstrate that traders derive pride and an important sense of professional accomplishment from the role they play in such forms of long-distance commerce - an aspect of being a trader that I have explored in detail in an earlier book, the focus of which was on the moral and ethical dimensions of the everyday lives and identities of long-distance traders from Afghanistan. ${ }^{17}$ In the remarks he made to me in St Petersburg, Zia also underscored, however, the extent to which traders must also contend with the visceral tensions and strains that come from being located at the interfaces of multiple geopolitical projects. The traders explored in the book are not merely savvy people able to instrumentally exploit the opportunities offered by tensions between competing geopolitical projects. Learning how to navigate fraught geopolitical contexts also has a palpable effect on their sensibilities and imaginations of the world. A central focus of Beyond the Silk Roads is on the way in which traders live and experience life in a world uneasily nestled between multiple geopolitical dynamics, and how doing so affects their everyday experiences, feelings, perceptions and imaginations.

17 Marsden 2016. 


\section{History, Culture and Ideology in Long-Distance Trading Networks}

A key finding of the research arising from the fieldwork on which this book is based is that commercial networks made up of individual traders play a critical role in connecting different parts of Asia to one another. Several excellent works by historians have gone beyond abstract and aggregate models of 'the Silk Road'. Instead, they have developed a 'Eurasian geographical frame' that brings together regions (Central Asia, South Asia and the Middle East) that have tended to be treated as distinct 'civilisations'. This approach emphasises the dynamism of Central Asian commercial networks, highlighting their 'pulsating structure' and the ways in which their collective activities were 'orchestrated' by multiple competing and collaborating groups'. ${ }^{18}$ It has brought attention to 'interlinked and entangled' histories of Eurasia while recognising that 'encounters and interactions could often lead to disconnections and constructions of difference'. ${ }^{19}$ In order to achieve these aims, historians have presented 'fine-grained' pictures of the 'people, places, contradictions, and experiences' that informed the make up of the specific networks that played a critical role in facilitating commercial, cultural and intellectual exchanges in modern Eurasia. ${ }^{20}$ These studies have emphasised the role played by ties of trust and commercial institutions in facilitating the operations and durability of such long-distance trading networks. They dwell on the powerful mechanisms developed and deployed by networks collectively to enforce shared standards of behaviour across long distances and emphasise the strategies and cultural forms developed by traders to communicate in complex multilingual and multicultural worlds. Shared commitments to religion and ethnicity have played a prominent role in the analysis of the internal coherence of such networks and their ability to withstand historical change over centuries. ${ }^{21}$ Of importance too has been the recognition of lingua francas, notably Persian, that are readily deployed by traders and other mobile people regardless of their specific cultural, religious and regional identities and backgrounds. ${ }^{22} \mathrm{New}$ approaches to the 'Eurasian arena' developed by historians do not treat the region as a fundamentally unitary 'civilisation': Eurasia, it shows, is helpfully conceptualised as a 'crossroads' of imperial, economic and cultural interactions - interactions that resulted in significant connections and commonalities but also powerful disconnections and divergences.

\footnotetext{
18 Levi 2020.

19 Khazeni 2014: 8-9. Cf. Fletcher 1995, Hodgson 1963, Subrahmanyam 2007.

20 Can 2020: 182. ${ }^{21}$ Cf. Aslanian 2014 and Trivellato 2009.

22 On the concept of 'the Persianate world', see Green 2019 and Sood 2016.
} 
There are striking similarities between the networks introduced in this book and those documented by historians. These similarities are visible in terms of the importance of understandings of trust to the traders' own analysis of the functioning of the networks to which they belong. They are also apparent in the ways in which networks cross vast territories and are made up of mobile individuals yet simultaneously also depend on their ability to anchor their commercial activities into specific nodes. In a manner reminiscent of Christopher Bayly's analysis of colonial India's 'information order', if networks enable the circulation of critical commercial and political information across long distances, then commercial nodes function as pools for the sharing of information and knowledge about opportunities and risks. ${ }^{23}$ Nodes are also the sites in which the reputations of individual commercial personnel are made and unmade, as well as producing the conditions in which networks reproduce themselves culturally, ideologically and sociologically - acting as emotionally pregnant spaces in which traders cultivate and embody shared sensibilities, establish families and reproduce community life. Finally, the networks operating across Eurasian contexts today - like those from the deeper past - are historically layered. As we shall see in the pages that follow, the contemporary shape of networks reflects modern geopolitical projects, but also the ongoing significance of past geopolitical and commercial arrangements. The networks thus layer together, paper over and mediate between multiple projects of Eurasian connectivity across space and time. Rather than approaching history in terms of it being a sequentially unfolding series of stages or periods, understanding the influence of Eurasian projects of connectivity on trading networks necessitates an approach towards time that is layered, overlapping and interpenetrating. ${ }^{24}$ And it also requires a concurrent conceptualisation of the networks' relationship to space that emphasises circulatory mobility rather than assuming that networks and diasporas are merely the transnational extensions of nation states and the 'ready-made' identities and categories they offer. ${ }^{25}$ Traders working in the markets of Eurasia today are not archaic hangovers from earlier forms of economic activity. Rather, studying them reveals the ways in which multiple histories are interleaved in an overlapping way in the trading networks they form. The diversity arising from such historical processes manifests itself in the ability of traders to be flexible in the face

${ }^{23}$ Bayly 1996. On Afghanistan's bazaars as nodes in an information order, see Karimi 2020.

${ }^{24}$ On the problems associated with fixating on the rupture between 'modern' and 'premodern' periods, Smail and Shryock 2013: 721-22. For a discussion on the significance of the recognition of overlapping temporal layers for the understanding of the historiography of Musim societies, see Bashir 2014.

${ }^{25}$ Mandal 2018; Cf. Gualtieri 2020. 
of geopolitical change and transformation; the traders attach value to this diversity and recognise the ways in which it enables them to respond to changing scenarios.

But studying the trading networks in the twentieth-first century by means of observing traders' everyday interactions with one another and the contexts they inhabit also illuminates aspects of trading networks that historians - dependent to a large degree on fragmentary documentary evidence - are rarely if ever able to explore in detail. Most importantly, a consideration of the lives of individual traders renders visible disjunctions between the public and collectively held aspects of commercial communities and the lived nature of their everyday lives. Anthropology's capacity to shed light on the distinctions between 'what is said' and 'what is done' in particular societies has for long been the discipline's mainstay. ${ }^{26}$ Exploring the terrain in between the representations that societies hold of themselves and the dynamics of such societies at an everyday level enabled anthropologists to go beyond stereotypes and generate complex models of social organisation - an approach that has also had a palpable influence on understandings of long-distance trade. ${ }^{27}$ Such complex models have simultaneously challenged and enriched the abstract approach of social theorists.

The distinction between what traders say about their networks and communities and their lived dynamics is most apparent in this book in relation to the ideas they hold about the importance of trust in their activities. Traders from vastly different communities share a collective emphasis on the important role played by relations and ties of trust in their mode of making a livelihood. Yet, in the context of their everyday lives, individual traders are often far more circumspect about the extent to which their commercial activities really arise from long-term ties of trust, as well as, when required, the successful enforcement of breaches of trust. Time and again, traders remark that they are successful not because of their ability to fashion ties of trust with those with whom they work; instead, they say, it is their ability to withstand mistrustful behaviour that best explains the durability of their activities over time and space.

Recognition of the imperfect workings of trust in the activities of longdistance traders shifts attention away from the conventional scholarly emphasis on the importance of long-term interpersonal relationships of trust that are often found in shared ethnic, religious or cultural backgrounds to the durability of trading networks. Beyond the Silk Roads underscores the need, instead, to emphasise the importance of the

${ }^{26}$ Malinowski 1992. $\quad{ }^{27}$ Cohen 1971 and Cohen 1969. 
flexibility of traders and the networks they form, as well as their ability to access and deploy in a contextual manner multiple cultural and ideological resources. ${ }^{28}$ Such flexibility, and the cultural and ideological multiplicity upon which its enactment relies, plays an important role in three major ways in the durability of the networks studied in this book: it informs their capacity to work with and between multiple geopolitical projects, to work across ideological and cultural divisions and to build social institutions that facilitate the overall activities of trading networks.

\section{Anthropology, Geopolitics and Informal Diplomacy}

It is impossible to understand vicissitudes in the fortunes of trading networks without addressing the ways in which the dynamics played out in the field of international politics affect them. The term 'geopolitical' has for over a century brought attention to the influence of physical space - rather than merely national territory - on the shaping of international dynamics. The sphere of geopolitics is widely regarded by scholars and analysts alike as being the preserve of the state. As a result, the term geopolitics is most generally associated with deliberate attempts made by state actors to control territories beyond their national boundaries and to influence actors belonging to other states.

If scholars assume that attempts to control territory matter most when they involve the state, then they have also long recognised the need to explore how such processes are affected by the intersection between local ideas about geography and the form taken by political organisations, ranging from those of the tribe to the modern state. ${ }^{29}$ There is also considerable recognition of the significance of local dynamics to the analysis of international political processes. ${ }^{30}$ Similarly, scholars of geopolitics have explored nation states' strategic use of diaspora and transnational communities in attempts to extend their reach, influence and even control. ${ }^{31}$ More recently, anthropologists and scholars in related disciplines have developed the concept of 'popular geopolitics'. The concept is most widely used to attend to the ways in which states seek to disseminate and materialise their geopolitical projects among local communities - communities that regularly inhabit contexts beyond the

${ }^{28}$ For a study emphasising the 'skills, expertise, and contacts' of Jewish traders active in the global trade in ostrich feathers, see Stein 2008: 10. For a critique of the deployment of trust in the analysis of trading networks, see Mathew 2019. Alessandro Monsutti employs the notion of 'trustability' rather than 'trust' per se to emphasise that the act of entrustment in Afghanistan is contingent on the availability of mechanisms that remedy breaches of trust (Monsutti 2013).

${ }^{29}$ See Dresch $1990 .{ }^{30}$ See Kwon 2010

31 Anderson and Clibbens 2018, King and Melvin 1999, Koinova 2017, Scheffer 1986. 
territories of the national boundaries of the states seeking to influence them. ${ }^{32}$ The strategies deployed by communities to 'deal with new regimes of control and (partially) open borders' have been explored most clearly through a focus on 'everyday processes of neighbouring', or 'collective and individual efforts to manage evolving relations' across international boundaries. ${ }^{33}$

Scholarly writing in this vein has been helpful in bringing attention to the effect of geopolitical processes on particular social and cultural contexts. Traders and mobile persons and societies, however, complicate such approaches in general and the notion of 'popular geopolitics' in particular. Such groups are not helpfully understood as 'locals' who are either merely on the receiving end of the geopolitical projects of nation states - such as the Belt and Road Initiative - or, alternatively, the actors that localise such projects in particular contexts. Instead, traders by definition make a living by moving things and persons across political boundaries, thereby challenging a dichotomous distinction between the local and the geopolitical. ${ }^{34}$ For the traders whose lives are explored in this book, making a livelihood in this manner both today and in the past has meant that the critical context in which they act is not a local site influenced by geopolitical forces arising from empires or nation states. The key context in which they act, rather, lies at the interface of multiple contests and struggles between empires and nation states over territory, influence and control beyond national boundaries. The political context in which Afghan traders act and position themselves is not best defined in terms of state boundaries but by historically shifting geographies of power, influence and control. In this context, it is unhelpful to see trading networks as the agent of one state or another, and the traders' agency as being constrained by the boundaries of the nation state. Instead, the traders and the networks they form are better thought of as being an important 'substrate of transregional political formations',35 - understanding them requires an approach that reflects the specificities of the geopolitical contexts that shape their modes of acting and interpreting the world. ${ }^{36}$

State actors are not the only category of person who seek presence, alliances and even control across borders. By acting as pivots between

32 The terms 'public diplomacy', 'popular geopolitics' and 'everyday' or 'informal' diplomacy have all been used by scholars to shed light on grounded ways of engaging with and responding to geopolitical processes. For an overview, see Marsden, Ibañez-Tirado and Henig 2016.

${ }^{33}$ Zhang and Saxer 2017: 12. $\quad{ }^{34}$ Humphrey 2018. $\quad{ }^{35}$ Anderson forthcoming (a).

36 On poetry as a window into the negotiation by Afghans of the geopolitics of imperialism, see Caron 2018. 
multiple states advancing different Eurasian geopolitical projects, Afghan traders also facilitate interactions between two or more nation states. Their ability to do this is not underpinned by 'diplomatic immunity' but, instead, their own skills of linguistic versatility and 'cultural immersion'. In order to play such roles, traders must learn and acquire the capacities that enable them to navigate the spaces betwixt and between inelastic, rigid and state-centric approaches to connectivity. ${ }^{37}$ Popular concepts such as the 'black economy' and the 'unregulated economy' posit the existence of entirely distinct economic domains. As several scholars have noted, however, 'legal and illegal, formal and informal, practices are intertwined in complex and fluid ways, and many people take part in both' ${ }^{38}$ It is a key contention of this book that understanding such 'fluid and complex worlds' requires an analysis not only of the intertwinement of formal and informal economic practices but also of actors' political and cultural skills and capacities. As we shall see, the traders with whom I work regard these skills and capacities as being of unique importance in determining their experiences and fortunes across Eurasia today.

Eurasia has been widely regarded by generations of geopolitical theorists as a physical space of special significance to international politics. In a manner that problematically reflects mid-twentieth-century European politics, some have regarded Eurasia as the 'heartland' of global power politics. ${ }^{39}$ Others, by contrast, argue that as a geographic category Eurasia is inherently elastic. As such, it is helpful because it blurs boundaries between multiple world regions including various parts of Asia and 'East and West Europe' and poses a challenge to 'neatly defined boundaries of the nation-state'. ${ }^{40}$ Another body of literature builds on the idea of 'civilisation' and urges recognition of the commonalities in Eurasia's social and political organisation in ways that transcend the constraints of narrow regions and the boundaries of the nation state. ${ }^{41}$

Eurasia's informal commercial terrain is in no sense level, horizontal or fluid. ${ }^{42}$ As in the past, networks able to call upon the support and protection of particular states and powerful holders of authority regularly find themselves better positioned to conduct commerce across this complex arena than those unable - or unwilling - to do so. ${ }^{43}$ Such forms of support and protection are of value not merely within the territories of the

37 Anderson 2020. $\quad{ }^{38}$ Van Schendel 2020: 41.

39 Bassin and Aksenov 2006 and Megoran and Sharapova 2014. ${ }^{40}$ Bloch 2017.

41 Hann 2015. ${ }^{42}$ Hann 2016.

43 In the nineteenth century traders from South and Central Asia often opted to trade in Ottoman territories under the protection of Russian and British consular support. See Stephens 2014. 
specific nation states with which traders identify. Given that being a merchant requires travel and regular mobility, traders invest with great significance the ability to count on the support of an influential state beyond one's home territory. A trader from Afghanistan able to call upon Turkish consular support in Saudi Arabia by dint of holding Turkish nationality, for example, is regarded by his compatriots as being better able to flourish in the Arabian Peninsula than a trader who relies solely on representation by the Afghan state - a political entity they regard as being weak. If, as we shall see, traders are mobile and adaptive in terms of their identities, they also recognise that such mobility depends on close ties and bonds with nation states and those in positions of power and authority. The traders recognise that the territories across which they work have been at the forefront of attempts by regional and global powers to extend and enhance their influence and power in transnational if not imperial ways; they are also clearly aware that if their economic activities are not recorded in a direct sense, then they do constantly engage in practices - ranging from travel to the transfer of capital - that states are able to, and indeed do, 'detect and record'. ${ }^{44}$ From the traders' perspective, there is little that is elastic in terms of their experiences of Eurasia, despite their living highly mobile lives and working across multiple settings.

The decade or so following the collapse of the Soviet Union saw greater levels of fluidity and mobility across Eurasia than had been the case at any point in time since the Bolshevik Revolution of 1917. By contrast, the years since 2001 have seen both superpowers and medium-size states seeking to use the state as the prime structure in the forging of interregional connectivity. This is most obvious, of course, in China's Belt and Road Initiative, but it is also apparent in Turkey's policy towards Asia, ${ }^{45}$ as well as in the role played by Russia in the establishment of a Eurasian Customs Union. ${ }^{46}$ Eurasia's 'far neighbours' - from the United States to the EU - have also been active in projects relating to the arena, sometimes launching projects, at other times being drawn into the region by smaller states in order to counterbalance the influence of its 'great powers'. ${ }^{47}$ Viewed from the perspective of these actors, such multiple geopolitical processes undermine the abstract scholarly understanding of Eurasian civilisational commonality yet further. The traders explored in this book often work in distinct geographical corridors, or pathways, of activity, which brings to light the importance of acknowledging the simultaneous importance of different geographic scales. As we see later in the book,

\footnotetext{
44 Van Schendel 2020: 41. $\quad{ }^{45}$ Aras and Fidan 2009, Bilgin and Bilgiç 2011, Lin 2016.

46 Cooper 2013. ${ }^{47}$ Peyrouse and Raballand 2015, Warkotsch 2011.
} 
Turkey's 'look east' policy, for instance, has invested the concept of West Asia with especially palpable relevance for many mobile traders whose lives criss-cross Turkey, the Gulf states and China but only infrequently penetrate post-Soviet, Eurasian worlds.

Trading networks that have been successful over time in modern Eurasian contexts are generally those that have worked flexibly with rather than against such a multiplicity of geopolitical projects. Rather than demonstrating loyalty to one or other geopolitical player, the capacity to navigate across the spaces in between multiple geopolitical projects is what has enabled them to survive and often flourish. A consideration of the trading networks active in present-day Eurasia reveals the importance for their durability of the ability to hitch themselves simultaneously to multiple and often competing geopolitical projects without becoming ensnared in the power dynamics and conflicts between them. In a manner comparable to the jihadists studied by Darryl $\mathrm{Li}$ and the Baluch networks documented by Ameem Lutfi, the traders explored in this world are protagonists in a connected Asia who simultaneously 'move beneath and between governments ${ }^{\text {' }} 8$ 'without being bound by anyone of them'. ${ }^{49}$

\section{Ideological and Cultural Complexity of Commercial Networks}

In a 2018 study, Rutger Claassen sought to develop a model of navigational agency. According to Claassen, this mode of agency requires that individuals and groups develop the ability to navigate between social projects at the same time as actively choosing in which social practices they do and do not wish to participate. ${ }^{50}$ The traders explored in Beyond the Silk Roads deploy navigational agency in their ability to weave between multiple geopolitical projects. Rather than emphasising the power and importance of choice for either groups or individuals, however, I suggest that a key principle of being a trader in the geopolitical interstices of Eurasian connectivity is that of pragmatically working with rather than against, and across rather than within, different geopolitical projects. A pervasive assumption in the scholarly literature on trading networks is that to be successful such networks must enjoy a strong degree of cultural and ideological coherence. ${ }^{51}$ By contrast, this book suggests that networks best able to navigate the spaces between Eurasia's multiple geopolitical projects are those that have access to multiple ideological and

\footnotetext{
${ }^{48}$ Li 2020: $5 . \quad{ }^{49}$ Lutfi 2018: 24. Cf. Alavi 2015. $\quad{ }^{50}$ Claassen 2018.

51 Werbner 2004.
} 
cultural resources. Being able to draw on a diverse and plural pool of ideological and cultural knowledge enables the successful navigation of choppy geopolitical waters by particular networks and communities.

A visit to the shop in Kabul of a trader who deals in goods imported from China underscored to me the extent to which traders consciously conceive of the acquisition of multiple cultural and ideological resources as being important for their future commercial and mobile trajectories. The trader had recently returned to Kabul after a year of living with his family in Istanbul. As is the case for many such Afghans seeking to conduct business in Istanbul, the man had been unable to establish a sustainable business in the city. Having returned to Kabul, he was worried about the mental health of his teenage children: confined to the family home in the city because of an increasingly volatile security situation, they complained of missing the stimulation of attending school in Istanbul. While he had tried to improve their self-confidence by buying a shop in a relatively secure building and putting them in charge of its stocklist, he was thinking about where he should send them for education in the future. In this context, he remarked to another man present - who lives in China and runs a trading office that exports goods to Ukraine 'my family have been sending our youngsters to Russia for education for years. I think now is the time that we also try something different. If we send our children to China too, they can meet their cousins educated in Russia in Kabul and create something new and different. It's time to follow two paths, not just one.' The man's remark aptly captures the degree to which traders do not regard themselves as the beneficiaries of one or other geopolitical project. The traders, rather, themselves recognise the ways in which their activities and modes of living mediate between and paper over contrasting geopolitical projects of Eurasian connectivity and regard this as being the key context in which they act and think.

Several anthropologists have explored the intersections between kinship and international politics in Asia. In particular, in the context of the divisive effects of colonialism and the 'global Cold War', as well as their afterlives, on Asian societies, they have analysed the role played by kinship and the family both as a 'site of struggle' but also in post-conflict 'community repair'. ${ }^{52}$ Kinship is not a central concern of this book. ${ }^{53} \mathrm{I}$ do, however, build on the insights of scholarship addressing the intersections of familial life and international politics. Beyond the Silk Roads explores

52 Kwon 2020. See also, Kwon 2013 and Bayly 2007.

53 On the ambiguous role that kinship relations play in the traders' lives and activities, see Marsden 2016. 
the collective strategies deployed by the members of trading networks to accrue multiple forms of not merely commercial but also cultural and ideological knowledge. Traders, it suggests, treat such forms of knowledge as critical resources that enhance their individual and collective ability to navigate across fraught geopolitical contexts. Importantly, however, traders often engage in such strategies of diversification at the same time as emphasising the importance of building contexts in which they can forge shared sensibilities, identities and ideas. I focus in a later chapter of the book, for example, on the important role played by the domain of the neighbourhood in maintaining the long-term durability of their networks. In the study of Muslim societies, there is widespread recognition of the extent to which neighbourhoods are thought about locally in relationship to the idioms of kinship, especially the notion of 'closeness'. ${ }^{54}$ The neighbourhoods explored in this book are very different from the bounded if changing urban settings explored by an earlier generation of anthropologists. Often geographically dispersed, they are also 'partial': to understand a neighbourhood in one context requires a consideration of its relationship to other connected neighbourhoods elsewhere. ${ }^{55}$ Such 'partial neighbourhoods', I suggest, enhance the durability of trading networks and do so in ways comparable with the important role that scholars such as Susan Bayly and Heonik Kwon have ascribed to the family in dealing with the divisive effects of colonialism and the Cold War. Partial neighbourhoods are emotionally resonant domains central to the creation and nurturing of shared sensibilities and identities; among the communities for whom such neighbourhoods are important, a great deal of energy, effort and resources is invested into their cultivation and sustenance.

The individuals who make up Eurasia's networks reflect, then, multiple layers of historical engagements across Eurasia. The palimpsest of influences they embody inform their collective and individual lives and identities, as well as those of the dynamics of the states in which they have lived and worked. As such, the lives and social relationships in trading networks reveal the way in which varying and often contradictory historical, cultural and ideological influences interleave with one another, challenging the assumption that ideological compatibility is the secret to collective commercial success.

\section{Trust and Mistrust in Long-Distance Trade}

The durability of trading networks depends not merely on the ability of individual traders to predict with accuracy the behaviour of the

\footnotetext{
54 Eickelman 1974. $\quad{ }^{55}$ On the notion of 'partial societies', see Ho 2014.
} 
commercial personnel with whom they work through the making of assessments about their 'trustworthiness'. As importantly, networks fashion institutions that comprehensively coordinate the 'pooling' of knowledge about commercial opportunities and dangers, shifting legal regimes and requirements and the reputations of individuals and collective commercial ventures. ${ }^{56}$ The term 'institution' inevitably brings to mind images of clearly defined economic and legal entities important for businesses: banks, firms, corporations and commercial courts. Yet this definition is too narrow to encompass the institution-building powers of merchants involved in the forms of commerce explored in this book. In the strictest sense of the term, an institution is 'an organization or other formal social structure that governs a field of action'. ${ }^{57}$ More recently, however, economists have given attention to the 'social institutions' important to the functioning of markets. Douglass North, for example, developed the term 'rules of the game' to identify social institutions comprising 'formal rules, informal constraints, and the characteristics of enforcing those constraints'. ${ }^{5}$ Social institutions, including formations such as ethnic trading communities, according to North, play a critical role in setting norms of accepted social behaviour.

Anthropologists have built on North's formulations but also brought attention to the need to identify the specific social contexts in which 'rules are implemented' and the 'beliefs and values' of actors maintained and sustained. ${ }^{59}$ In doing so, anthropological scholarship builds on an earlier body of literature that brought widespread attention to the importance of durable social structures in societies that had hitherto been regarded as primitive or anarchic, most especially the so-called tribal societies of Asia and Africa. ${ }^{60}$ This book builds on this important tradition in anthropological scholarship. It suggests, however, that the institutions central to the organisation and durability of the traders' activities is not the network they form in aggregate. I suggest, instead, that greater attention needs to be placed on the traders' ability to fashion institutions that they collectively regard as being central to their activities. In the chapters that follow, then, I document how traders regard marketplaces (bazaarha), hotels and restaurants (hotalha), as well as religious and cultural associations (anjomanha) as key aspects of their activities and institutions (sazmanha) of which they themselves are the authors.

Many scholars writing about diaspora and migrant communities have emphasised the role that the social institutions they have fashioned play in shaping and maintaining cultural identities in the context of migration

\footnotetext{
56 Anderson 2020. $\quad{ }^{57}$ Oxford Bibliographies 2017. $\quad{ }^{58}$ North 1992.

${ }^{59}$ Hann and Hart 2011: $91 .{ }^{60}$ Evans Pritchard 2013.
} 
and mobility. ${ }^{61}$ Such institutions, I suggest in this book, also coordinate the circulation and exchange of knowledge, commodities and people and are therefore indispensable to a trading network's success and durability. As we shall see in the following pages, such circulations and the forms of regional connectivity in which they result are very different from the official models that envisage formal agreements between nation states leading to expansions in the volume of trade and cultural exchanges between specific settings. Instead, the circulations on which this book focuses are the result of hard work. They arise from intimate knowledge of multiple settings, societies and polities - knowledge that individuals and communities that are frequently the foci of restrictive policy on the part of national and international political forces garner over decades if not generations.

\section{Religious Plurality and Long-Distance Eurasian Trade: Past Meets Present}

Religious plurality features strongly in historical studies of long-distance Eurasian trade and commerce. Sikhs and Hindus from Afghanistan played a major role in the trade between South and Central Asia, for example, establishing communities in the Muslim-majority khanates of Central Asia. ${ }^{62}$ Jews were critical to the trade between the Muslim-majority societies of Central and West Asia. The city of Isfahan in Iran, for example, was for centuries a major node for the activities of Armenian Christians across Muslim-majority Asia. ${ }^{63}$ Similarly, Muslim merchants from the historic entrepôt of Bukhara settled in such far-flung places as Siberia and the Russian city of Orenburg - an important commercial node in which they traded in silks, cotton and natural products, such as rhubarb. ${ }^{64}$ Bukharan merchants also travelled to China, acting between the sixteenth and midnineteenth centuries in particular as the middlemen for the trade in goods between China and Europe. ${ }^{65}$ In the deeper past, Sogdian traders based in Central Asia established the main caravan networks that connected China and India to Europe between the fifth and seventh centuries CE. ${ }^{66}$

By contrast, the focus of much international media coverage of Eurasia today is on the pressures facing communities that are now classified as forming 'ethno-religious minorities'. ${ }^{67}$ From Muslims in China's western

\footnotetext{
${ }^{61}$ See Tölölyan 2000. $\quad{ }^{62}$ Levi 2002 and Markovits 2000. ${ }^{63}$ Aslanian 2014.

${ }^{64}$ Monahan 2015. ${ }^{65}$ Levi 2017. ${ }^{66}$ Vaissière 2018.

67 On the process through which Christians and Jews in the Arabic-speaking world had to choose between being 'a cloistered, dependent "minority" and belonging to an anticolonial nationalist majority' in the context of the decline of the Ottoman Empire and the rise of the postcolonial nation state, see Makdisi 2019: 123.
} 
Xinjiang autonomous region to Sikhs and Hindus in Muslim-majority Afghanistan, to Bukhara's historic Jewish communities, ethno-religious minorities from across a spectrum of traditions that historically played a pivotal role in long-distance trade have been directly affected by repressive state policies, authoritarian governments, civil and military conflict and movements of politically oriented religious reform and purification. In many contexts, this has led to the mass emigration of Eurasia's ethnoreligious minorities. Bukhara's Jews have now mostly relocated to Tel Aviv and New York's Queens neighbourhood, ${ }^{68}$ while Afghanistan's Sikh and Hindu communities currently number only 500 or so families in the country itself - since the onset of civil war in 1992, most have moved to cities in South Asia, Western Europe and North America. ${ }^{69}$ Chinese policies in Xinjiang are resulting in the emigration of China's Uyghurs and Kazakhs to settings across Asia, Europe and North America; scholars also interpret these policies as reflecting an active policy of the 'Sinicisation' of China's western frontier and the forms of Islam present in that contested geopolitical space. ${ }^{70}$ Historian Nile Green argues that such processes reflect the broader bleaching out of the historic cosmopolitanism of Asia's Muslim-majority urban centres: cities such as Kabul, Herat and Bukhara that were once home to flourishing ethno-religious minorities have also become entirely Muslim as the communities that once lived within them have sought refuge beyond Asia. ${ }^{71}$

This book charts the effect of such population movements on the sociological make up of Eurasia's commercial personnel. The infamous money market - the Sarai Shahzada - that lies at the heart of Kabul's historic commercial district (Mandawi) was once predominantly home to businesses run by Jewish, Sikh and Hindu moneylenders. ${ }^{72}$ Today, those operating businesses out of it are largely Farsi- and Pashto-speaking Muslims. Bukhara's Jewish neighbourhood is now home to but a handful of Jewish families, while no Jews currently reside in the Jewish neighbourhood located in the ancient Afghan city of Herat. Sikh gurdwaras and Hindu temples in Kabul and Ghazni have fallen into disrepair as 'new entrants' into the world of trade from the country's provinces master the skills of business and trade. ${ }^{73}$

68 Cooper 2012 and Baldauf, Gammer and Loy 2008. $\quad{ }^{69}$ Marsden 2018.

70 Thum 2014. ${ }^{71}$ Green 2016. ${ }^{72}$ Chaudhury forthcoming and Chaudhury 2020.

73 Many of Afghanistan's established trading families left the country in the 1970s and 1980 s and relocated themselves and their capital to countries in the Americas and Western Europe. A significant majority of the traders whose lives are explored in this book hail from families that turned from agriculture and state employment to trade from 1970s onwards. See Marsden 2016 
Such transformations have undoubtedly led to major shifts in the ethos underlying long-distance trade and commercial activity. But modes of doing business have also been transmitted across religious boundaries widely held as being impenetrable. An Afghan Muslim setting up a business in Moscow or Odessa, for instance, is likely to have started by selling goods purchased on credit with Hindu and Sikh merchants who are also of Afghan nationality. Similar stories are important in 'global cities' around the world, especially in Western Europe (London and Hamburg most notably) and in the Middle East (most obviously in Dubai). Ethnic Turkmen traders from northern Afghanistan - leading players in developing the country's fabled business in handwoven carpets in the 1960s - often recount their interactions with internationally connected Jewish carpet and antique dealers from Central Asia. ${ }^{74}$ There has been a displacement of ethno-religious trading minorities from Eurasia's commercial nodes. Yet what is notable is the ongoing importance of ethno-religious minorities to the forms of long-distance trade across the area, albeit in the new settings and nodes in which dispersed communities have established themselves. The undeniable depletion of ethno-religious diversity in Eurasia's historic trading nodes has not simply resulted in the death of the old modes of doing business and forms of sensibility with which these were entangled. These have, rather, re-emerged in a new and different range of 'sites of interaction', adapting and altering as they have done so. ${ }^{75}$

\section{Alternative Geographies}

Conventional geographies of the so-called New Silk Road often dwell on the transformative significance of new ports and specially constructed commercial 'hubs' for Eurasian economic and political connectivity. New or redeveloped ports in the Persian Gulf - such as the Indian- and Iranianfunded Chabahar in Iran or the Chinese-built Gwadar in Pakistan - will facilitate connectivity between India and the Central Asian states and China and the maritime routes of the Indian Ocean. ${ }^{76}$ Scholarship also emphasises the ways in which such hubs will extend the military reach of global and regional powers into spaces that fall well beyond their 'sphere of influence' ${ }^{77}$ Similarly, political decision-making processes affecting trade and commerce across Eurasia are widely analysed in terms of government policies arising out of influential Eurasian capital cities: Beijing, New Delhi, Istanbul, Riyadh, Dubai and Moscow, most notably. ${ }^{78}$ There is also growing recognition of the strategies deployed

\footnotetext{
${ }^{74}$ See the preface in Cordell 2018. $\quad{ }^{75}$ Harper and Amrith 2012. $\quad{ }^{76}$ Anwar 2013.

77 Daniels 2013. ${ }^{78}$ Friedman 2019.
} 
by 'emerging' states - such as Kazakhstan, Azerbaijan and Mongolia - to navigate their relationships in a field overcrowded by 'great players'. ${ }^{79}$

Existing analysis of the intersections between geographies of economic and political power in the Eurasian arena reflects the wider tendency for scholars to address regional dynamics through the lens of the nation state. $^{80}$ The overwhelming emphasis in much work that purportedly concerns regional connectivity is actually on the role played by nation states or formal associations of nation states - such as the Shanghai Cooperation Organisation - in forging and eroding connectivity across national boundaries. Scholars critical of this tendency within and beyond Eurasia have developed the term 'methodological nationalism' to illuminate the powerful assumption visible in much scholarly and popular discourse that the world is naturally ordered in relationship to nation states. ${ }^{81}$ As I have suggested, this tendency is even more visible in the study of geopolitics, a field within which virtually the only type of actor conceived as being relevant is the nation state. Instead, scholars in the humanities and social sciences have increasingly called for recognition of the significance of regional contexts and communities that cross the boundaries both of the nation state and the regions upon which nation states are often problematically assumed to have emerged. ${ }^{82}$ The nation state system is rarely the best lens through which to understand the dynamics of such communities and contexts. This approach brings attention to the social, cultural, political and economic interpenetration of 'transregional' contexts that criss-cross both nation states and a 'particular scale of region'. ${ }^{83}$ It also argues that the 'culture-areas' in relationship to which scholarship and policy have been organised - such as those of South and Central Asia - are premised on notions of cultural purity and origin, similarity and difference, which are themselves connected to conceptions of national identity. For historians, work in this vein has called for critical historicisation of conventional 'conceptions of place, origin and selfhood', and growing emphasis is being placed on studying linkages across polities and regions. 'To be a Persian', Mana Kia argues, for example, 'was to be embedded in a set of connections with people we today consider members of different groups. ${ }^{84}$ If historians have emphasised the need to study historic transregional geographic contexts without extrapolating the narrow frame of interstate relations on to the past, then anthropologists have questioned the assumption that the nation state is always the most important force in the organisation of

\footnotetext{
79 Yolaçan 2019b and Bulag 2014. $\quad{ }^{80}$ Malkki 1995.

81 Wimmer and Glick Schiller 2002. $\quad{ }^{82}$ Freitag and von Oppen 2010.

${ }^{83}$ Kia 2020: $12 .{ }^{84}$ Ibid.: 4.
} 
contemporary forms of politics, economy and identity. Anthropologists have pointed to specific types of communities, groups and societies, especially those inhabiting 'borderlands', that are of special analytical value for attempts to understand the social and political dynamics of transregional societies. ${ }^{85}$

In an especially insightful article published in 2017, for example, anthropologist and historian Engseng Ho challenges the tendency to frame regional connectivity in terms both of 'transnationalism' and of 'diaspora studies'. Ho has urged, instead, for recognition and analysis of 'mobile societies', which he defines as 'small, mobile, and less integrated' social formations. Ho suggests that such societies have not traditionally been the focus of social scientists because of the emphasis placed in social theory on large-scale social and political aggregates. 'Mobile societies', he argues, are spatially dispersed and made up of individuals with multiple allegiances, loyalties and identities; they are also often fashioned over decades if not centuries of movement, exchange and interaction. ${ }^{86} \mathrm{Ho}$ identifies mobile societies as being 'partial': their overall dynamics can only be understood if multiple contexts are investigated and analysed alongside one another.

A consideration of transregional contexts through empirical studies of mobile societies rather than of communities identified on the basis either of their transgressing or of upholding national boundaries reveals the ongoing significance of histories of connectivity that are older than those associated with relations between modern nation states. As I discussed earlier, the networks explored in this book layer together, paper over and mediate between different historical projects of Eurasian connectivity that have involved states seeking presence, alliance, influence and sometimes control across national boundaries. As such, it is unhelpful to think of the networks as narrowly 'transnational': the context with which they must contend, adapt to and profit from is not one merely of nation states but of overlapping and interpenetrating historical influences shaped by forms of political activity that project power across national, regional and cultural boundaries.

In an earlier book, I explored the ways in which the Afghan traders whom I studied held varying and often critical ideas about the extent to which the national identity category 'Afghan' reflected their personal and collective identities. Yet they also developed their own - often embodied understandings of 'being Afghan'. Doing so allowed traders to recognise and relate to one another in a manner that questioned the overwhelming

${ }^{85}$ Van Schendel 2002. ${ }^{86}$ Ho 2017: 907-08. 
salience of markers of religious, regional and ethnolinguistic identity and facilitated the making of complex commercial relationships that crossed such boundaries. ${ }^{87}$

The focus of this book is also on traders and networks that share a history of entwinement with the territories that make up Afghanistan, as well as its state structures and the identity categories these have played a powerful role in creating. But the book avoids treating Afghanistan simply as a site from which trading communities have been historically dispersed. Afghanistan is also a context that has been historically significant for the activities of multiple mobile societies and has also been affected in complex ways by the projection of power by empires and modern-day nation states. In this sense, internal and external movements, circulations and inter-Asian connections have informed and shaped the make up of Afghanistan's societies, social and political structures, communities, commercial practices and cultures. We shall see in this book the extent to which the country's social and cultural composition is redolent with vital expressions of such transregional dynamics and connections, and how it is through these that traders connected to the territories that make up modern-day Afghanistan influence multiple Asian contexts in both economic and cultural ways. ${ }^{88}$

The mercantile individuals and groups with whom I have worked while conducting the research on which this book is based relate to and identify with Afghanistan in diverse and contested ways. Some collectively identify with the nation state of Afghanistan and think of this as being a natural and authentic source of identity and political structures. For others, however, Afghanistan is a colonial and postcolonial political construct that has marginalised regional identity formations and histories. A trader I had come to know in China, for example, took me on a visit to his home village in Afghanistan's Panjshir Valley. During the course of the journey from Kabul, he drew my attention to a few words of graffiti written in Persian on a large rock standing over the fast-flowing river at the narrow defile that marks the start of the valley; the graffiti read: 'We are not Afghan' (ma afghani nistim). For this trader, the term Afghan refers to the country's Pashto-speakers and erases the identities of Farsi-speakers in the country such as himself. Many of the traders from Afghanistan neither embrace nor entirely reject their categorisation in relation to the nation-identity category 'Afghan'. There are contexts in which it is helpful to analyse the traders

87 Marsden 2016.

88 On Afghanistan's global connections over the longue durée, see Crews 2015. 
described in this book in relationship to national identity; in many others, their identities and histories are more helpfully viewed through the lens of mobile societies, partial communities and transregional connectivity.

A central focus of the ethnography presented in this book, for example, are two communities that are historically connected through commerce and migration to multiple Asian settings yet also deeply immersed in Afghanistan. The two communities relate to the category 'Afghan' in different ways. A consideration of the modes in which they do so disrupts the widely held notion that Afghanistan is best thought of as a site of dispersal and that its migrant communities have inevitably formed 'diasporas'. Instead, such communities reveal that Afghanistan's networks, if generally conceived of in scholarly, economic and geopolitical terms as being peripheral, are actually critical players in wider inter-Asian dynamics.

Chapter 2, for instance, explores the activities of traders who identify as 'Bukharan'. These traders' families entered Afghanistan in the 1920s in the wake of the Bolshevik Revolution in Central Asia. Today, they live and work in Saudi Arabia, Turkey and Pakistan - few have returned to Afghanistan since leaving the country in the late 1970s. For them, Afghanistan did not constitute a homeland in any one-dimensional sense; instead, the country was more akin to a 'way station' in which they had spent time. Yet it was a way station that had long-lasting and important implications for their community and its identities as well as collective experiences - many such families continue to hold Afghan citizenship because the countries in which they are based (especially the UAE and Saudi Arabia) have not granted them citizenship. In this way, Afghanistan is not a straightforward homeland or site of dispersal for this community, yet nor is its importance to this group simply that of a temporary site of refuge. It is instead a context deeply relevant and integral to their activities and identities but not in a manner that is exclusivist or bounding.

Similarly, the focus of Chapter 3 is on the role played by Sikh and Hindu traders in contemporary expressions of Eurasian connectivity. Today based in Moscow, Odessa, Amsterdam and London, early generations of Afghanistan-based Sikhs and Hindus previously played a pivotal role in both finance and trade in Afghanistan, especially in the transit trade that saw goods moving in a multidirectional nature between Central and South Asia. Their past lies in the pioneering role that Indian merchants played in the trade between South and Central Asia between the seventeenth and nineteenth centuries. In the 1960s and 1970s, Sikh and Hindu traders based in Kabul played an 
important role in the official trade between Afghanistan and the Soviet Union. While being connected to Afghanistan is an important aspect of the identity of Sikhs and Hindus, so too is a longer history of mobility across an Asia-wide arena. This longer history requires an analysis that goes beyond not only the nation state but also the notions of 'home' and 'host' societies associated with much work on diasporas. It requires recognition, instead, of historical embeddedness of mobile societies across multiple and interconnected contexts.

Mobile societies such as Afghanistan's 'Bukharans' and the country's Sikhs and Hindus reveal especially acutely the limitations that arise when regional connectivity is approached narrowly from the perspective of specific nation states. Indeed, they require forms of analysis that go beyond assessing the ways in which historic connections have shaped and influenced the nation states in which people live today. Instead, they bring to light the importance of studying communities that are distributed geographically across Asia yet are interconnected with one another across both space and time. This book explores the movements, adjustments and nodes of interaction that have been important for mobile societies and partial communities. It focuses on contingent shifts in identity formation important for these societies and addresses the ways in which these relate to transforming geopolitical initiatives and circumstances. Under exploration are the ways in which merchants identify their own backgrounds, identities and collective histories in changing ways according to the varying circumstances in which they operate.

The forms of Eurasian connectivity explored in this book require us to delve into the ways in which traders and mobile merchants actually do connect different parts of Eurasia, rather than relying on powerful images of the states and international organisations that depict how they think such connections should look. This not only necessitates visiting places that conventional accounts rarely consider of any significance to interregional connectivity; it also requires recognition of the ways in which such places are of significance to settings they are infrequently considered in relationship to. For a trader with an Afghan background in Ukraine, the ability to import the toy scooters on which his livelihood depends to the Black Sea port of Odessa from the Chinese trading city of Yiwu is intricately connected to his ability to raise capital in Kabul. Capital flows from Kabul to Odessa enable the transport of merchandise from China to Ukraine. Exploring Eurasia from the inside out reveals alternative geographies and entanglements of culture, politics and economy with which these are entangled. 


\section{Plan of the Book}

Conventional understandings of the New Silk Road frequently rehearse the utopian understanding of such projects as arising out of the historic east-west flows that characterise official narratives about them. ${ }^{89}$ Similarly, approaches more critical of international diplomacy tend to reduce the analysis of megaprojects to a power play between geopolitical forces of varying scales, be these superpowers, emerging powers or spoilers - smugglers and militants of various stripes, for example - who inhabit the so-called 'spaces in between'. What both approaches omit are the nature of on-the-ground realities and the historically informed perspectives and experiences of individuals, networks and communities that are involved in the fashioning of interregional connections. This book brings attention to the multiple actors on the ground who possess a great deal of insight into how to survive and prosper in such a contested geopolitical environment.

The carefully managed and regulated flows of commodities, goods, products and people envisaged in the Belt and Road Initiative is likely to constrain rather than facilitate the flourishing of the social, cultural and political skills that are necessary for durable forms of regional interconnectivity. Fieldwork has demonstrated that such visions squeeze the livelihoods of communities in Eurasia's borderlands. ${ }^{90}$ Since the collapse of the Soviet Union, the inhabitants of such contexts have benefited from informal trans-Asian connections by dint of their geographic location and knowledge of local conditions. The declining significance of smaller-scale traders and the diplomatic yet socially valued capacities they display on a daily basis also stands to erase an important social mechanism for helping to ensure that multiple conflicts across the region's numerous boundaries do not erupt further. The granular, jagged and jarring - in short, un-silky - roads explored in this book should not be treated as informal and illegal and thereby inevitably a security threat or a risk. They are, rather, monuments to the creative activity of people who have been poorly served by the nation state and the international system over previous decades. It is in this context that they have built their own structures, institutions and sensibilities, both for life and for commerce. Chapter 1 offers insights into the mode of fieldwork on which the book is based and the contributions that such research can make to the anthropological study of geopolitics. It focuses in particular on the importance of 'mistrust' to the traders' universes and relationships, and asks how traders and anthropologists live and work in contexts in which 'everyone is an agent'.

${ }^{89}$ Simpfendorfer 2009. $\quad{ }^{90}$ Mostowlansky and Karrar 2018. 
Chapters 1, 2, 3 and 4 explore networks and nodes that are of significance for inter-Asian connectivity. Chapters 2 and 3 focus on two different inter-Asian human-commercial corridors. Together, the chapters demonstrate that Afghan merchants simultaneously connect multiple parts of Asia to one another. The chapters highlight in particular the capacity of merchants active across both corridors to navigate between competing Eurasian geopolitical projects advanced by great powers acting within and beyond Asia, including Russia, Turkey, China and, in its role as a 'distant neighbour', the United States. And they suggest that recognising the sophistication of commercial actors in the field of geopolitics is something that can have important implications for the strategies that smaller nation states squeezed between their more powerful neighbours are seeking to develop. The corridor of connectivity documented and explored in Chapter 2 connects post-Soviet Eurasia to China via the Muslim-majority states of Central Asia. Chapter 3 focuses on a West Asian corridor of connectivity that connects Turkey, the Hijaz and Central Asia in a triangle.

Chapter 4 takes the reader to a commercial city that has become central for the organic forms of connectivity explored in this book - Yiwu International Trade City, located in China's commercially powerful Zhejiang province. It describes the ways in which Eurasian geopolitics are imprinted on the city's physical and social spaces, as well as its development over the past two decades as a site of China's global connections. The chapter analyses tensions between the visions that Chinese policymakers hold of Yiwu's place on the Belt and Road Initiative and the types of aspirations and feelings that international traders living there hold about its current and future significance for their commercial activities and communities.

Chapter 5 turns its attention to the significance of ethno-religious minorities to Eurasian connectivity. It focuses in particular on the activities and identities of Hindu and Sikh traders who hold Afghan citizenship but now largely work in markets, both in post-Soviet Eurasia and Western Europe. In the face of the 'de-cosmopolitanisation' of Muslim Asia's historic cities, this chapter makes the case for recognising the ongoing vitality of an older legacy of living and doing trade in culturally complex urban settings.

Having focused on networks, nodes and communities, the book's final empirical chapters address the significance of social institutions and specific practices to the forms of Asian connectivity upon which it focuses. Chapter 6 focuses on the notion of alternative geography by means of a discussion of the importance of Afghanistan not as a site of dispersal but of the circulation of capital required for the movement of people and 
things. This chapter also tackles head on the widely held assumption that 'trust' is central to the workings of trade networks. It analyses instead the significance of contingency and dynamism to the durability of trading networks and brings attention to specific practices and financial instruments in relationship to which traders organise their activities in deeply uncertain worlds.

Building on the preceding consideration of financial instruments and practices, Chapter 7 considers the importance of social institutions to the functioning of the jagged roads explored in the book, focusing in particular on restaurants and eateries. At one level, the chapter's consideration of the distribution of Afghan restaurants and eateries in Asia's trading nodes demonstrates that the country's assumed status as peripheral to Asian dynamics needs questioning not only in the sphere of finance but also that of culture. Not merely sites of pleasure and the building of relationships of trust through acts of hospitality and food-sharing, restaurants are also sites of critical significance for the pooling of knowledge about commerce and reputation. This function of restaurants is invested with heightened significance and value in geopolitically fraught settings characterised by pervasive forms of mistrust in which 'everybody is an agent' - restaurateurs as well as traders are required to demonstrate skills in the arts of living geopolitics.

The conclusion sums up the overall findings of the book and explores the future prospects for mobile societies, trading networks and the cultural and commercial geographies with which these are connected. 